\title{
Fc Receptor
}

National Cancer Institute

\section{Source}

National Cancer Institute. Fc Receptor. NCI Thesaurus. Code C17070.

Receptors found on the cell surface of some B-lymphocytes, T-lymphocytes, and macrophages, which recognize the Fc (constant region fragment) portion of immunoglobulin molecules. 